\title{
Development of Audio Watermark Technology to be Extracted Contactlessly by Cell Phone
}

\author{
Toshio Modegi Member (Dai Nippon Printing Co., Ltd., e-mail: Modegi-T@mail.dnp.co.jp)
}

\begin{abstract}
Keywords : audio watermark, lossless, contactless extraction, cell phone, analogue robustness, sound source location
\end{abstract}
We have proposed a novel audio watermarking technology, which embeds a set of bitstream data by changing two-channel stereo locations of lower frequency components in an embedding target audio signal. As this embedding method modifies locations of only lower frequency components, whose locations cannot be recognized definitely, this enables nearly lossless watermark embedding. In this paper, we propose an extended monaural audio watermark embedding method, which supports both monaural and stereo audio signals, and enables watermark detection by a single monaural microphone or a cell phone.

Our proposed three embedding methods shown in Fig. 1 can be categorized by an embedding data area dimensions as a spatial division (stereo method), a frequency division and a temporal division (two kinds of monaural methods).

Figure 1-(1) shows our basic concept of watermarking for stereo audio signals. This embeds a set of given bitstream data by changing two-channel stereo locations of lower frequency components in an embedding given audio signal. In each separated audio frame, a single tri-state code $(-1,0,+1)$ is embedded. The panning location of lower frequency components (around less than $200 \mathrm{~Hz}$ ) will be changed to the left in case of the embedded code -1 , changed to the right in case of the code +1 , and changed to the center in case of the code 0 . This method will not modify any frequency components except for the lower-frequency sound source direction, which we (human beings) can not clearly recognize. Even if we modify the quality of each channel component, the embedded codes will not disappeared as far as the volume balance of two channels is maintained. Therefore, this method features nearly lossless embedding, robustness against lossy data compression or analogue conversion. And we have confirmed a contactless detection capability of embedded watermarks through speaker and microphone devices.

In order to contactlessly extract the embedded watermarks on the previously proposed method, we have to use stereo dual-directional microphone. This restricts strictly microphone receiver positions and requires enough sound source output energy. Therefore, we proposed two kinds of extended methods as shown in Fig. 1-(2) and (3), by which we can detect watermarks with a monaural microphone. These improved methods enable detection by non-directional monaural miniature microphone units embedded in such as mobile voice recorder or cellphone devices.

Figure 1-(2) method embeds a set of given bitstream data by changing the level balance of two-band divided low frequency components in a monaural signal or stereo left-channel signal. Figure 1-(2) indicates, the component of the first band will be removed in case the embedded code is +1 , the second band will be removed in case of the code -1 , and both bands will be removed in case of the code 0 . The removed components will be transferred to the corresponding frequency position of the right channel if exists. This method has robustness against an extracting frame phase shift, but may be easily influenced by lower frequency distortions of acoustic transmission systems such as speaker and microphone device characteristics.

Figure 1-(3) embeds a set of given bitstream data by changing the level balance between two temporally divided sub-frame low frequency components, in a monaural signal or stereo left-channel signal. The component of the first sub-frame will be removed in case the embedded code is +1 , the second sub-frame will be removed in case of the code -1 , and both sub-frame will be removed in case of the code 0 . The removed components will be also transferred to the corresponding frequency position of the right channel if exists. Different from the Fig. 1-(2), this method has robustness against lower frequency characteristic distortions but is likely to be influenced by a phase shift.

In both proposed monaural embedded cases, if the embedded audio signal is played back by stereo, the right-channel can be used for compensating the components removed from the left channel. Therefore, these monaural methods support also nearly lossless watermark embedding if the source is stereo. For cell phone extraction usages, our experiments support, the third temporal division method is the most appropriate.

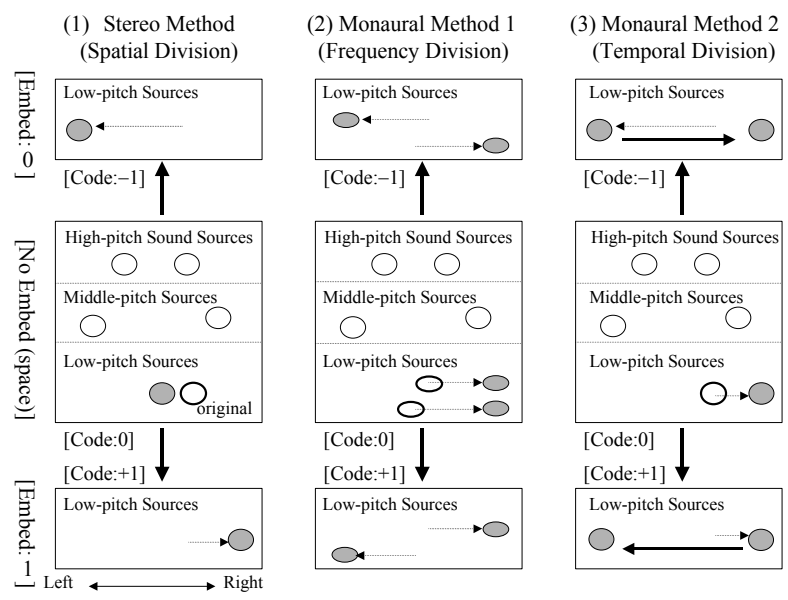

Fig. 1. Three Kinds of Proposed Audio Watermark Embedding Methods 


\title{
論 文 \\ 携帯電話で非接触抽出可能な音楽電子透かし技術の開発
}

\author{
正 員 茂出木 敏雄*
}

\section{Development of Audio Watermark Technology to be Extracted Contactlessly by Cell Phone Toshio Modegi*, Member}

We have proposed a novel audio watermarking technology, which embeds a set of bitstream data by changing two-channel stereo locations of lower frequency components in an embedding target audio signal. This method features nearly lossless embedding, robustness against lossy data compression or analogue conversion, and enables contactless asynchronous detection of embedded watermarks through speaker and microphone devices without the original audio signals.

Then, we propose several extended monaural embedding methods, which embed data by changing level balances between two sets of lower frequency components, which are divided by either frequency or temporal dimensions. In these level changes, we remove lower frequency components of the left channel signal and add the removed components to the corresponding components of the right channel of given stereo signal in order to support also nearly lossless embedding. These methods enable watermark detection from only the left channel signal by a single monaural microphone, and we have confirmed detection capability by a cell phone.

In this paper, we describe abstracts of our proposed watermark embedding and extracting algorithms, experimental results of watermark extraction precision.

キーワード : 音楽電子透かし, ロスレス, 非接触抽出, 携帯電話, アナログ而性, 音源定位

Keywords : audio watermark, lossless, contactless extraction, cell phone, analogue robustness, sound source location

\section{1. まえがき}

これまで音楽に対してデジタル的に電子透かしを埋め込 む種々の手法が提案されているが, 音質に少なからず劣化 を伴い, MPEG 等のロッシー型圧縮や, ライン信号やスピ 一カ/マイクを経由したアナログコピーにより, 埋め込み 情報が維持されないという問題があった。

文献(1)では MPEG と同様なマスキング処理を用いた埋 め込み手法を提案し, 文献(2)では MPEG の対象外の低周 波領域にデータを埋め込む方法を提案することにより， MPEG 圧縮に対するロバスト性を改善している。文献( 3 ) ではスペクトラム拡散法を用いてアナログ変換に対するロ バスト性を改善している。しかし，いずれの手法も音質を 多少犠牲にし, あらゆる攻撃に適応できるロバスト性を備 えていると言い難い。特に画像の透かし分野では，携帯電 話のカメラ等を用いた非接触な透かし検出技術が既に開発

\footnotetext{
* 大日本印刷株式会社

情報コミュニケーション研究開発センター

T162-0066 東京都新宿区市谷台町 6-3

Media Technology Research Center,

Dai Nippon Printing Co., Ltd.

6-3, Ichigaya-Daimachi, Shinjuku-ku, Tokyo 162-0066
}

されているが(4), 透かしが埋め込まれた音楽をマイクロフォ ン等により非接触に検出する技術は現状実現できていな い。また, 文献(8)ではロスレス型の電子透かし埋め込み手 法を提案しているが, 同文献で提案されているような素材 合成再生形態でないと適用できず，汎用性のあるロスレス 型の埋め込み手法も現状実現できていない。

そこで筆者らは，一般の 2 チャンネルステレオ音楽デー タに対して, 低周波領域の定位を, 埋め込む情報ビットに 基づいて偏移させる方法を用いた新規な電子透かし埋め込 み手法について提案した(5)。提案手法は, 全体的な音楽品質 には殆ど影響を与えず, MPEG 等のロッシー型圧縮やアナ ログ変換の影響を受けにくいという特徵をもち, スピーカ /マイクロフォンを経由した非接触検出が可能であること も確認している。また, 透かし検出側は, 単純な FFTによ る信号処理で簡便に実現でき，オリジナルデータを使用せ ずにリアルタイム検出処理を実現している(5)。

しかし，非接触検出においてステレオマイクを必要とし 実用性に乏しかったため, ステレオの片側チャンネルに対 してモノラルマイクを向けるだけで検出できるように改良 を加えた ${ }^{(6)}$ 。更に, 携帯電話のマイクロフォン感度特性や音 声圧縮に適応できるように, 埋め込み方式を改良してきた 
(7)(9)。

本稿では, 先提案の電子透かし埋め込み方式の概要と改 良方式の信号処理系について述べる。続いて, 改良方式の 性能評価として，あらかじめ各方式にて楽曲情報が埋め込 まれている音楽 CD の再生音を, マイクロフォンや携帯電 話を用いて非接触にキャプチャを行い，埋め込み情報を抽 出する実験を行なったので，その結果を報告する。

\section{2. 先提案の電子透かし埋め込み方式}

〈2・1〉 ステレオ埋め込み方式の概要 図 1 に先に提 案した電子透かし埋め込み手法の原理を記す(5)。一般的な 2 チャンネル・ステレオ音楽信号に対して低周波成分を抽出 し, 埋め込むビット情報に基づいて，その低周波成分の定 位を一定の時間間隔で左端 $(-1)$, 右端 $(+1)$, またはセンタ 一(0)に変化させる。即ち, 左チャンネル成分のみ, 右チャ ンネル成分のみ, 左右チャンネル均等の 3 通りに再分配す る。ここで，データを 3 值にすることにより， -1 と+1を 埋め込みビット情報に割り当て, 0 をバイト間の区切りなど 同期をとるためのスペースに使用することができる。

本手法により埋め込まれた音楽信号は，低周波成分の定 位が移動するだけであるため, 全体的な音楽品質は殆ど原 音と同じである。そして, ヒトの音源定位感覚は低周波で は鈍感であるため, 埋め込まれた低周波成分の定位の移動 については殆ど認識できない。具体的には $100 \mathrm{~Hz}$ 前後以下 の成分についてはヘッドフォンで視聴しても変位を判別で きない。更に, 埋め込まれた情報は, 種々の方法でロッシ 一型圧縮が行われても, アナログ系を経由しても，2 チャン ネル間の信号バランスに顕著な偏移が起こらない限り消失 することは無くロバスト性を備えている。

〈2·2〉 モノラル埋め込み方式の概要

図 2 の左側は 前述の提案方式 1 に基づいて透かしが埋め込まれた音楽に 対して，1本のステレオ・マイクロフォンを用いて非接触抽 出を実現する構成を示す。問題は左右音のクロストークを 抑えるため, マイクロフォンの指向性を上げ，スピーカか

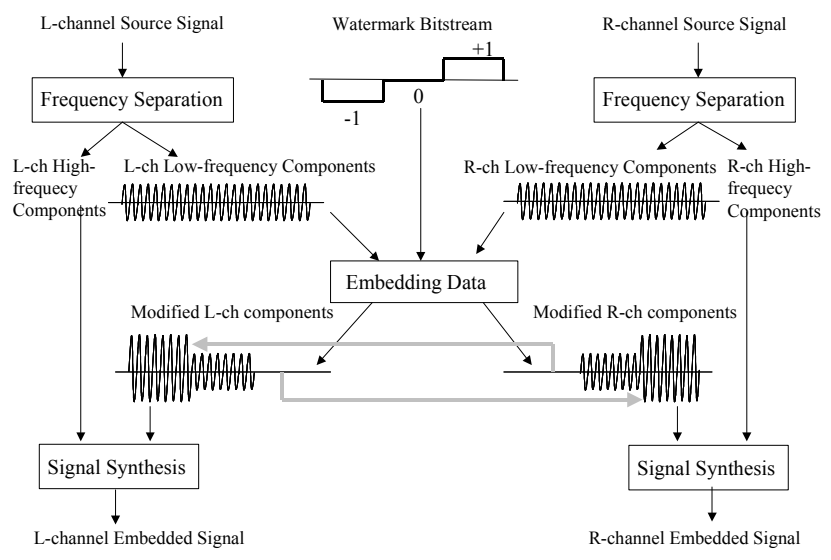

図 1 先提案のステレオ埋め込み方式

Fig. 1. Previously Proposed Stereo Embedding Method.

ら等閒隔の距離に配置する必要がある点にある。その結果， 低周波領域の感度低下と入力音圧レベルの減少につなが り，マイクロフォンのわずかな摇れが検出ミスにつながる。 これに対し, 低周波の埋め込み領域を 2 バンドまたは 3

[Stereo Embedding Method]

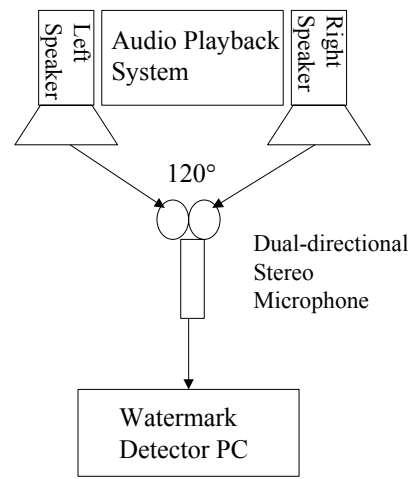

図 2 マイクロフォンによる非接触抽出方法

Fig. 2. Contactless Extraction Methods by using Microphones.

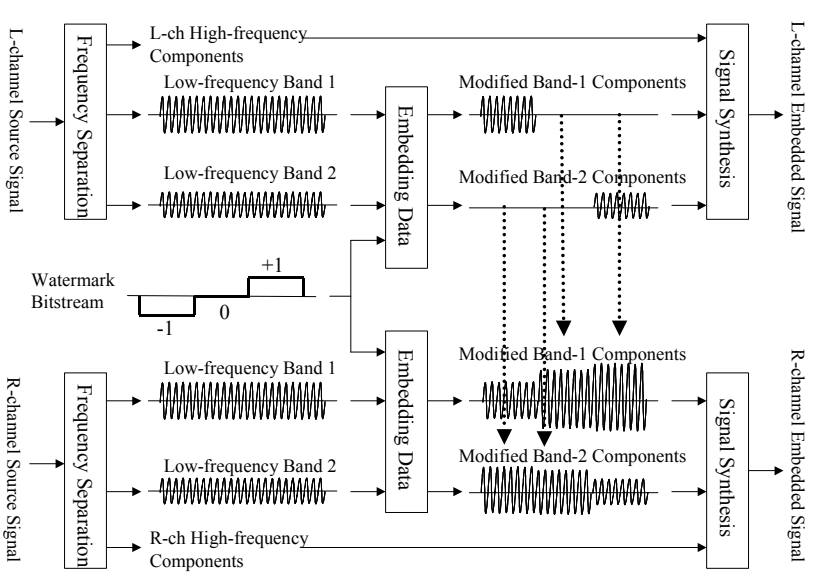

図 3 モノラル埋め込み方式 1 の処理概要

Fig. 3. Abstract of Monaural Embedding Method 1.

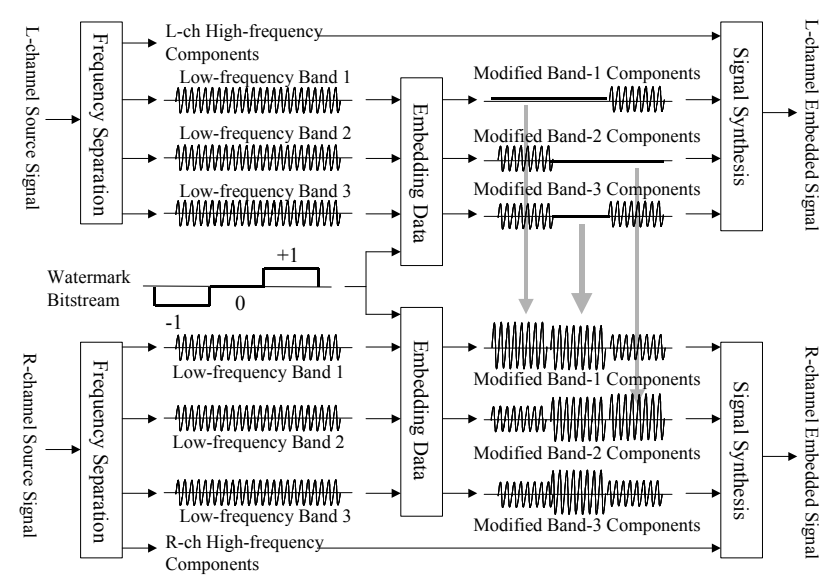

図 4 モノラル埋め込み方式 2 の処理概要

Fig. 4. Abstract of Monaural Embedding Method 4. 
バンドに分割し，バンド間における音源位置をデータに基 づいて互いに反転させながら，モノラル信号に対して透か しを埋め込む方式を提案した ${ }^{(6)}$ 。

具体的には, 図 3 または図 4 に示されるようにモノラル 信号（ステレオの場合は L チャンネル）上の 2 バンドまた は 3 バンド成分のいずれかを削除することによりバンド間 比率を変化させ，ステレオの場合は，削除した成分を $\mathrm{R}$ チ ヤンネル側の対応する領域に移動させることにより，ほぼ 原音質を維持することができる。

一方, 透かしの抽出は, 図 2 右側のように, ステレオ信 号の場合でも L 側チャンネルだけで, モノラル・マイクロ フォンにより行なえる。そのため, 前述のクロストークの 問題は無くなり, 指向性を上げる必要が無いため, 低周波 領域の感度が低下寸ることもなく, スピーカに近づけるこ とが可能になるため十分な感度で精度の良い検出が行なえ る。更にマイクロフォンを若干摇らせても検出が可能にな るため, 特にモバイル用途に適している。

\section{3. 改良型の電子透かし埋め込み方式}

〈3.1〉 先提案の問題点と改良方式の提案 図 3 で示 されるモノラル埋め込み方式は, 低周波領域の感度特性の 影響をもろに受けやすく，それに改善を加えたのが図 4 の 方式であるが，特に携帯電話等で検出を行なう際には，こ れでも不都合が生じやすい。ここで，これまで文献(5)(6) で提案してきた手法を概念的に整理すると, 図 5 の左列お よび中央列のようになる。即ち，ステレオ埋め込み方式は 空間分割方式であり，モノラル埋め込み方式は周波数分割 方式であるといえる。残された手法は時分割方式で, 文献 (7)(9)では, 図 5 の右列に示されるような時間軸方向に分 割してデータを埋め込む方法を提案した。

具体的には, 図 6 に示されるようにモノラル信号（ステ レオの場合は L チャンネル) の各フレームを 2 分割し, 分 割フレームの前後一方または双方を削除することにより分

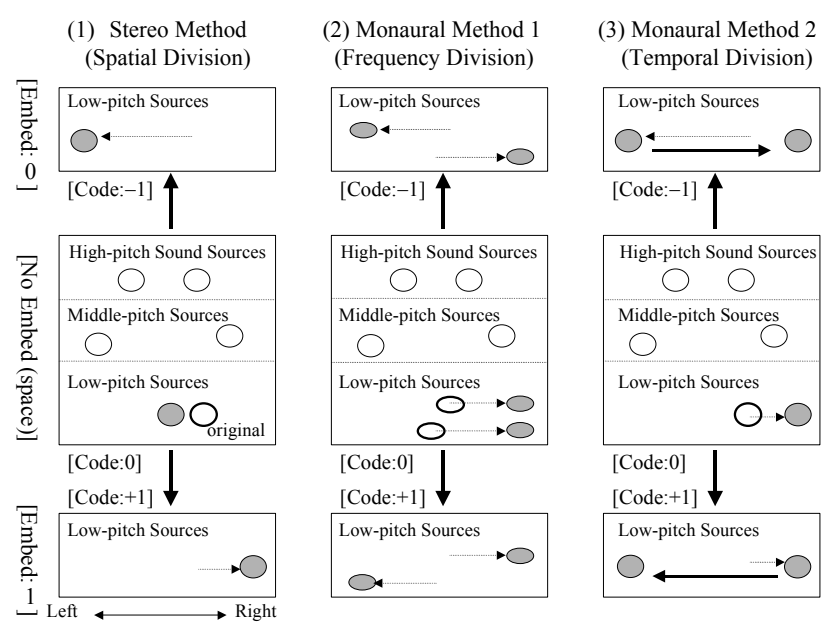

図 53 つの電子透かし埋め込み方式の概念

Fig. 5. Three Concepts of Watermark Embedding Methods.
割フレーム成分間比率を変化させ，ステレオの場合は，削 除した成分を $\mathrm{R}$ チャンネル側の対応する領域に移動させる ことにより，ほぼ原音質を維持することができる。この時， 逆に L チャンネル側で削除されなかった分割フレームに対 応する R チャンネル側の成分を削除して, L チャンネル側 に移動させることもでき, これにより抽出精度を向上させ ることができる。このような $\mathrm{R}$ チャンネル側から L チャン ネル側への成分移動は, $\langle 2 \cdot 2\rangle$ 節で述べた図 3 , 図 4 の既 提案方式にも適用することができる。本稿では, 文献(7)(9) で提案した時分割方式を基本に, 空関数形状に工夫を加え, 位置ずれの影響を受けにくく, 高感度な抽出を可能にする 改良時分割方式の詳細アルゴリズムについて述べ, 図 1, 図 3 で示される方式の詳細は文献( 5 )(6)に譲るものとする。

\section{〈3・2〉 電子透かし埋め込みアルゴリズム}

$\langle 3 \cdot 2 \cdot 1\rangle$ ステレオ音響信号の周波数次元変換 サン プリング周波数 $F$ のソース音響信号に対して, 空幅 $N$ で固

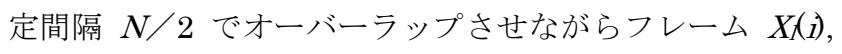
$X_{r}($ I $)(i=0, \cdots, N-1)$ を抽出し, 以下のように離散フーリエ変換 を施す。奇数フレームに対しては, 後述する 3 種類の空関 数 $W_{k}(\imath),(k=1,2,3)$ を用いて 3 回離散フーリエ変換を行い, 偶数フレームに対しては, 第 4 の窻関数 $W_{4}($ ( ) を用いて 1 回 離散フーリエ変換を行い, それらの変換されたデータの実 部を $A_{l k}(j), A_{r k}(j)(j=0, \cdots, N-1, k=1,2,3,4)$, 虚部を $B_{l k}(j)$, $B_{r k}(\jmath)(j=0, \cdots, N-1, k=1,2,3,4)$ とする。ソースがモノラル信 号の場合, $X_{r}(\mathrm{l}), A_{r k}(\jmath), B_{r k}(\jmath)(k=1,2,3,4)$ は常に 0 として以 下処理を行えば良いが, 埋め込みにより低周波成分の音質 劣化を伴う。 $k=1,2,3,4$ において,

$$
\begin{aligned}
& A_{l k}(j)=\sum_{i=0, N-1} W_{k}(i) X(i) \cos (2 \pi i j / N) \\
& B_{l k}(j)=\sum_{i=0, N_{-1}} W_{k}(i) X(i) \sin (2 \pi i j / N) \\
& A_{r k}(j)=\sum_{i=0, N_{-1}} W_{k}(i) X_{r}(i) \cos (2 \pi i j N) \\
& B_{r k}(j)=\sum_{i=0, N_{-1}} W_{k}(i) X_{r}(i) \sin (2 \pi i j N)
\end{aligned}
$$

ここで, 4 種の窓関数 $W_{k}(\eta)(k=1,2,3,4)$ として, ハニング 空関数 $W(\mathrm{I})=0.5-0.5 \cos (2 \pi i / N)$ を基本として, 図 7 に示さ れるような形状に変形配置したものを提案する。文献

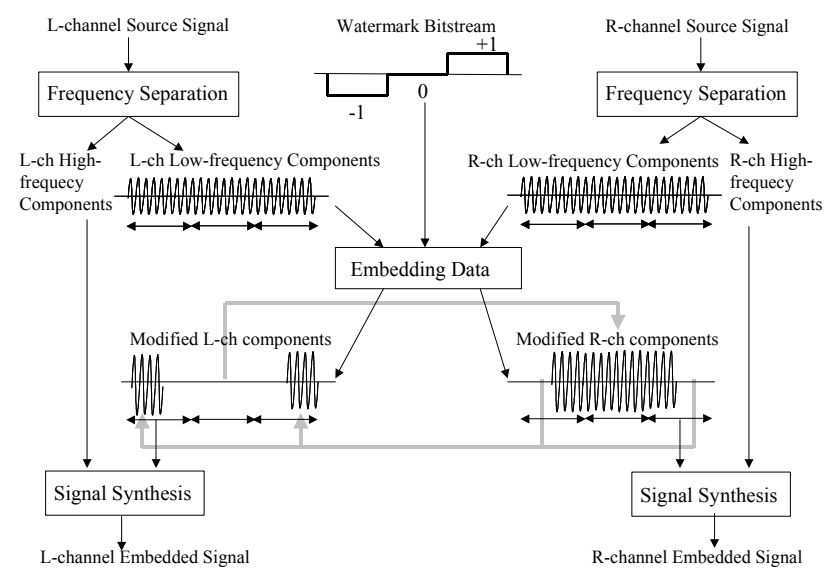

図 6 モノラル埋め込み方式 3 の処理概要

Fig. 6. Abstract of Monaural Embedding Method 3. 


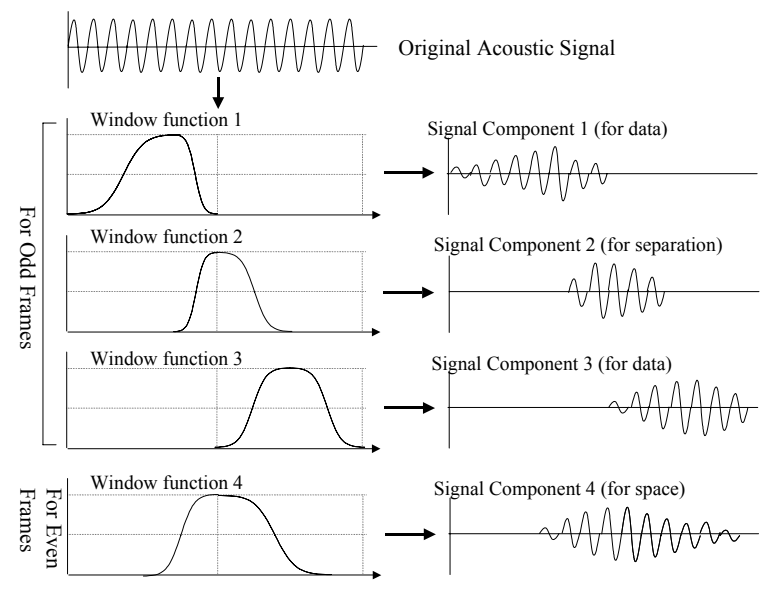

図 74 つの空関数の定義事例

Fig. 7. Examples of Four Kinds of Window Functions.

(7)(9)においては, 奇数フレームと偶数フレームに同一の ハニング空関数を使用し, 奇数フレームではハニング空を 3 分割して 3 つの空関数を定義していた。本稿では, データ の抽出感度・精度を向上させるため, 以下のような非対称 な窓関数を定義するようにした。

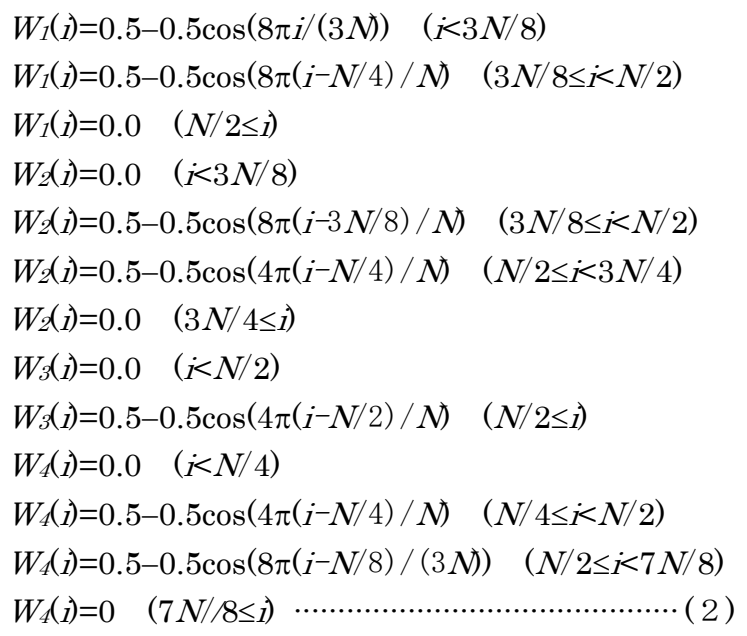

$\langle 3 \cdot 2 \cdot 2\rangle$ 低周波成分の変換 はじめにデータを埋め 込む対象である奇数フレームに対して変換方法を説明す る。フーリエ変換データの実部 $A_{l 1}(j), A_{l 3}(\mathrm{~J})(j=1, \cdots, M)$, 虚 部 $B_{11}(\jmath), B_{13}(j)(j=1, \cdots, M)$ に対して, まず以下総パワーを算 出する。

$$
\begin{aligned}
& E_{1}=\Sigma_{j=1, M}\left\{A_{11}(j)^{2}+B_{11}(j)^{2}\right\} \\
& E_{2}=\sum_{j=1, M}\left\{A_{13}(j)^{2}+B_{13}(j)^{2}\right.
\end{aligned}
$$

$M$ は埋め込み低周波領域の上限值で, $N=4096$ でサンプ リング周波数が $44.1 \mathrm{kHz}$ の場合， $M=20$ (約 $200 \mathrm{~Hz}$ までの 低周波成分）に設定するのが適当である。 $1 \leqq j \leqq M$ につい て以下のような変換を行う。尚， $L_{0}$ は埋め込みを行なうこ とが可能なレベル下限值である。

(1) $E_{2}>L_{o}$ かつ埋め込みデータが +1 の場合

$k=1,2$ において下記式(4)を実行し, 抽出精度を向上さ
せるため更に $k=3$ において式( 5 )を実行する。

(2) $E_{1}>L_{o}$ かつ埋め込みデータがー 1 の場合

$k=2,3$ において下記式(4)を実行し, 抽出精度を向上さ せるため更に $k=1$ において式( 5 )を実行する。

（3）上記以外(埋め込みデータ 0 の場合を含む) $k=1,2,3$ において下記式( 4 )を実行する。

$$
\begin{aligned}
& E_{k}(\eta)=\left\{A_{l k}(j)^{2}+B_{l k}(j)^{2}+A_{r k}(j)^{2}+B_{r k}(j)^{2}\right\}^{1 / 2} \\
& A_{r k}{ }^{\prime}(\jmath)=A_{r k}(\jmath) E_{k}(\jmath) /\left\{A_{r k}(j)^{2}+B_{r k}(j)^{2}\right\}^{1 / 2} \\
& B_{r k}{ }^{\prime}(\jmath)=B_{r 1}(\jmath) E_{1}(\jmath) /\left\{A_{r 1}(j)^{2}+B_{r 1}(j)^{2}\right\}^{1 / 2}
\end{aligned}
$$$$
A_{l k}{ }^{\prime}(j)=0, B_{l k}{ }^{\prime}(j)=0
$$

$$
\begin{aligned}
& E_{k}(\jmath)=\left\{A_{l k}(j)^{2}+B_{l k}(j)^{2}+A_{r k}(j)^{2}+B_{r k}(j)^{2}\right\}^{1 / 2} \\
& A_{l k}{ }^{\prime}(j)=A_{l k}(\jmath) E_{k}(\jmath) /\left\{A_{l k}(\jmath)^{2}+B_{l k}(j)^{2}\right\}^{1 / 2} \\
& B_{l k}{ }^{\prime}(\jmath)=B_{l k}(\jmath) E_{k}(\jmath) /\left\{A_{l k}(j)^{2}+B_{l k}(j)^{2}\right\}^{1 / 2} \\
& A_{r k}{ }^{\prime}(j)=0, B_{r k}{ }^{\prime}(j)=0
\end{aligned}
$$

続いて，偶数フレームのフーリエ変換データの実部 $A_{14}(\jmath)$ $(j=1, \cdots, M)$, 虚部 $B_{I 4}(j)(j=1, \cdots, M)$ に対しては, 無条件に $k=4$ において式(4)を実行する。

〈3·2·3〉 ステレオ音響信号の時間次元逆変換 前節 での述べた埋め込み処理を行った結果を各々 $A_{l k}{ }^{\prime}(\jmath), B_{l k}{ }^{\prime}(j)$ $(k=1,2,3,4)$ とすると, 更新されるフレームのデータ $X i(i)$, $X_{r}^{\prime}\left({ }^{\prime}\right)$ は, 以下のように, 上記変換されたスペクトルに対し てフーリエ逆変換を行った結果と, 原フレーム $X(\mathrm{I}), X_{r}(\mathrm{I})$ と空関数による加重平均となる。奇数フレームでは,

$$
\begin{aligned}
& X_{l}(\jmath)=1 / \mathrm{N} \sum_{k=1,3}\left\{\sum_{j=0, N \_1} A_{l k}(j) \cos (2 \pi i j / N)\right. \\
& \left.-\sum_{j=0, N-1} B_{l k}(j) \sin (2 \pi i j / N)\right\} \\
& +\left\{1-\sum_{k=1,3} W_{k}(I)\right\} X(I)
\end{aligned}
$$

となり, 偶数奇数フレームでは,

$$
\begin{aligned}
& X_{I}(I)=1 / \mathrm{N}\left\{\Sigma_{j=0, N \_1} A_{l 4}(j) \cos (2 \pi i j / N)\right. \\
& \left.-\sum_{j=0, N_{-} 1} B_{l 4}(j) \sin (2 \pi i j / N)\right\} \\
& +\left\{1-W_{4}(I)\right\} X(l) \\
& X_{r}(\grave{l})=1 / \mathrm{N}\left\{\sum_{j=0, N \_1} A_{r 4}(j) \cos (2 \pi i j / N)\right. \\
& \left.-\sum_{j=0, N-1} B_{r 4}(j) \sin (2 \pi i j / N)\right\} \\
& +\left\{1-W_{4}(I)\right\} X_{r}(I)
\end{aligned}
$$

となる。以上の手順で原音響信号の低周波成分にデータが 埋め込まれる様子を図 8 に示す。

〈3·3〉電子透かし抽出アルゴリズム＼cjkstart埋め込まれた 音響信号に対して, 場合によりアナログ系を含む各種信号 変換系を経由して, サンプリング周波数 $F$ でデジタル化さ れた離散音響データの左チャンネル成分 $X(l)(i=0, \cdots, N-1)$ に対して, $\langle 3 \cdot 2 \cdot 1\rangle$ 節と同様なフーリエ変換を行い, 埋め 込夕領域の実部を $A_{11}(j), A_{13}(\jmath)(j=1, \cdots, M)$, 虚部を $B_{11}(j)$, $B_{13}(j)(j=1, \cdots, M)$ とする。尚, 全ての右チャンネル成分 $X_{r}(\mathrm{I})$ および, 左チャンネルの $A_{12}(\jmath), B_{12}(\jmath)$ と $A_{14}(\jmath), B_{14}(\jmath)$ 成分は抽 出時には算出不要である。 
[Low frequency parts of original signal]
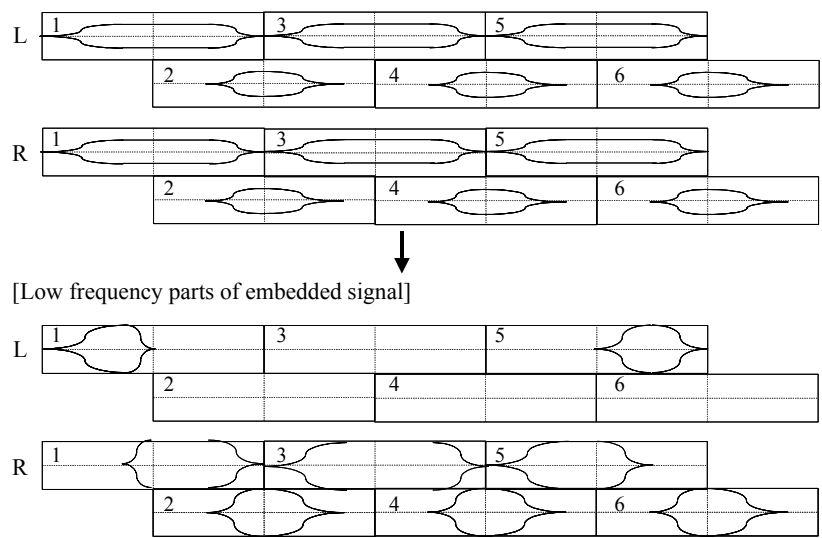

図 8 各フレームへのデータ埋め込みシーケンス

Fig. 8. Data Embedding Sequences for Each Frame.

アナログ系を通すと, 埋め込み時と抽出時の低周波領域 のレベルは大幅に変化するため, $L$ は埋め込み時に設定した $L_{o}$ の值に対して, 抽出時の平均信号レベルを基に動的に増 減させる必要がある。また, 埋め込み時の周波数範囲は 1 $\leqq j \leqq M$ であるが，境界部は周辺成分の影響を受け，特にア

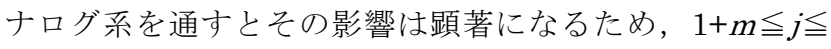
$M-n （ m$ と $n$ は正の整数で, 例えば $m=1, n=2$ に設定 $)$ な る周波数範囲の縮小補正を施し，以下計算を行なう。

$$
\begin{aligned}
& E_{1}=\Sigma_{j=1+m, M_{-n}}\left\{A_{11}(j)^{2}+B_{11}(j)^{2}\right\} \\
& E_{2}=\sum_{j=1+m, M_{-} n}\left\{A_{13}(j)^{2}+B_{13}(j)^{2}\right\}
\end{aligned}
$$

上記算出した $E_{1}$ と $E_{2}$ の比率に基づいて符号判定を行な い, 左右比率は 2 程度が適当である。

(1) $E_{2}>L$ から $E_{2} / E_{1}>2$ の場合，符号を +1

(2) $E_{1}>L$ かつ $E_{1} / E_{2}>2$ の場合, 符号を -1

(3) 上記以外は符号を 0 とする。

〈3.4〉 ワードデータ列の埋め込み方法埋め込み対 象の音響信号の低周波領域のレベルはコンテンツにより変 動し，随所に埋め込みできないフレームが発生する。そこ で, 基本的に可変長のビットデータ形式で埋め込み, 埋め 込むデータは 8 ビットの文字列や圧縮された可変長ワード でも対応できるようにした。

レベルが小さくて埋め込みができない場合およびビット データ列の区切りを示すデータとして 0 を埋め込み, 0 と 0 の間にー 1 または+1のビットデータ列を連続して配置させ る。そして 0 に続くビットデータ列の先頭に, 後続するビ ット列が新規ワードの先頭ビットか現ワードの継続ビット かを識別するフラグを 1 ビット分挿入する。

図 9 は本提案に基づき, 8 ビット固定長のバイトデータ列 の埋め込み事例を示す。上段は, 8 ビット固定長で 2 バイト のデータを埋め込んだ標準的な事例で，下段は途中でレベ ルが小さいフレームに遭遇したため, バイト内のビット列 を分断して埋め込んだ事例である。

〈3.5〉抽出時のフレーム位相補正方法 アナログ入 力を行った音響サンプルから埋め込みデータを抽出する際

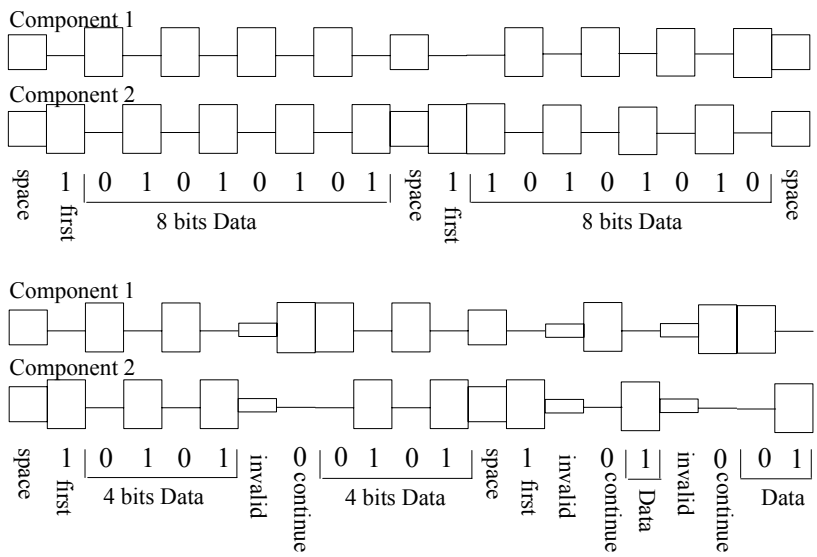

図 9 バイトデータ列の埋め込み事例

Fig. 9. Embedding Example of Byte Data Arrays.

(1) Watermark Embedded Signal

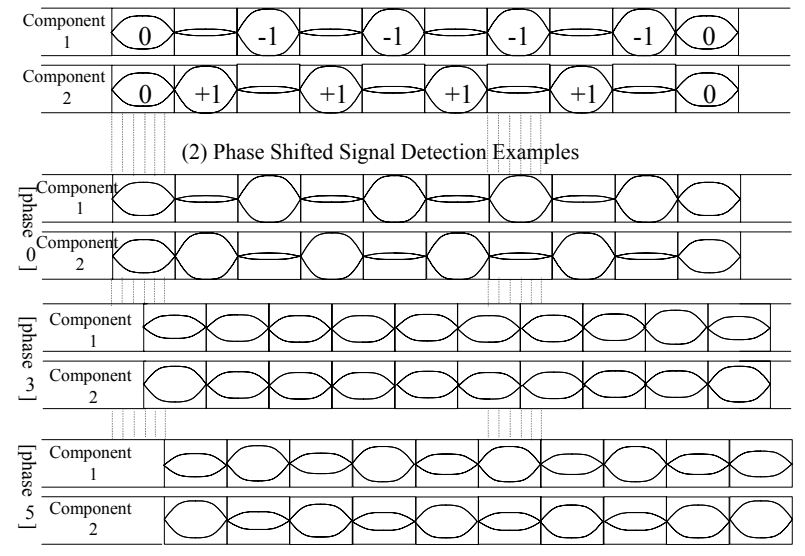

図 10 抽出時のフレーム位相補正の事例

Fig. 10. Example of Frame Phase Adjustment.

は，まず埋め込み時のフレームに同期させる必要がある。 文献 ( 7 )で提案したよう空関数を対称的に分割させてデー 夕を埋め込む方法をとると, 調度 $1 / 2$ フレームだけ位相が ずれと, ビットが反転してしまうという問題があった。本 提案手法では非対称な空関数を時系列に配置させて時系列 にデータを埋め込む方法をとっているため, この現象は軽 減させる。本稿では, スピーカやマイクなどのアナログ系 を経由して入力を行った音響信号に対しても高精度な抽出 が行なえるように, 文献( 7 )で提案した位相補正より厳密な 補正方法を提案する。

基本的には, 文献 $(7$ ) と同様に, 図 10 で示すような 6 段 階の位相ずらしを各フレーム単位に行ない, -1 または+1 のフレームにおいて, 最も第 1 成分と第 2 成分の成分の比 率が顕著になる位相シフト条件を探索し, その条件で符号 判定を行なう。この時, 埋め込夕時のフレームとのずれが 段階幅の半分くらいになると, 最適な位相シフト条件の判 定が不安定になり, ビット判定エラーが発生しやすくなる。 そこで, 判定された位相シフト条件の変動を検出したら, 段階幅に比べて微小量だけ抽出対象の音響信号のアドレス 
をずらすようにする。位相シフト条件が安定するまで，こ の処理を継続するようにすれば，最適な位置まで自動的に 誘導できる。尚, このような処理を加えても, パソコン上 でのリアルタイム処理に支障ないことを確認している (1GHz-PentiumIII パソコン使用)。

\section{$\langle 3.6\rangle$ 埋め込み時における最適化処理 $\langle 3 \cdot 2 \cdot 2\rangle$ 節} で述べたように，埋め込み時には対象フレームの信号レ心゙ ルをチェックし，抽出が困難と予想されるレベル下限值 $L o$ 未満では埋め込みを行なわないようにしている。データを 埋め込んだデジタルデータの状態で，アナログ変換や位置 ずれ発生が起こらない条件で抽出実験を行なうと, 下限值 を超えていても抽出エラーが発生する場合があり，逆に下 限值を下回っても抽出に成功する場合があり, 周囲のフレ 一ムの信号レベルの影響を受けることが判明した。

そこで, 図 11 に示寸ように, 埋め込み処理と抽出・ベリ ファイ処理を繰り返し行う方法を提案する。埋め込み処理 では, 直前に行なわれた抽出ログファイルを参照してエラ 一が発生したフレームにはデータの埋め込々を行なわない （符号 0 を埋め込む）ようにし，各フレームに埋め込んだ結 果を埋め込みログファイルとして出力する。抽出・ベリフ アイ処理では, 直前に行なわれた埋め込みログファイルを 参照しながら, 抽出結果と比較し, 相違があればエラーフ レームとして抽出ログファイルに出力する。これらの処理 を, 抽出・ベリファイ処理でエラーフレームが全く生じな くなるまで繰り返すと, 最も高精度に最大容量のデータが 埋め込まれた音響信号を生成できる。

抽出・ベリファイ処理は，アナログ系を通した音響信号 で行なら方がベターとも考えられるが，上記処理で最適化 を行なったときと同一のアナログ系（同一のスピーカやマ イクロフォンを使用）で運用しないと，その効果が出ない。 現実には，そのような制約を設けることが難しいため，デ ジタルデータの状態で処理する方が無難である。

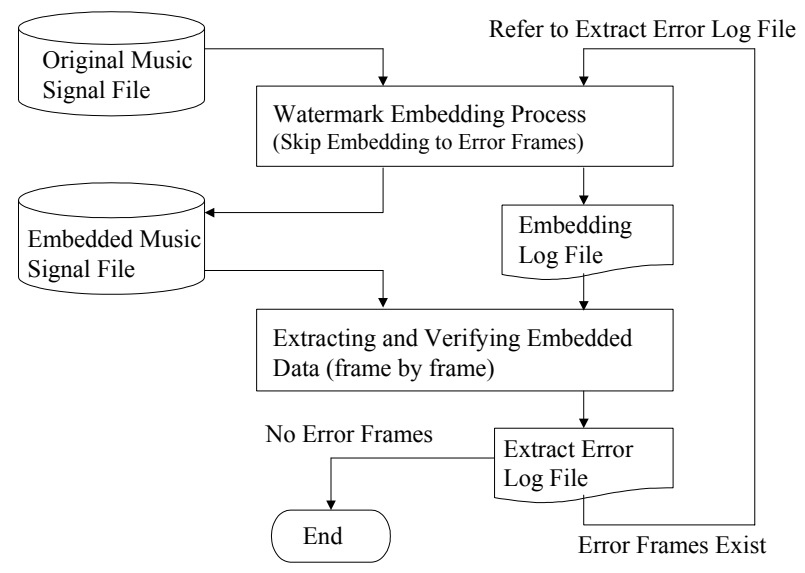

図 11 反復埋め込み処理による最適化手法

Fig. 11. Optimization of Data Embedding by Repetitive Embedding Processes.

\section{4. 提案手法の評価実験}

先の提案手法および本稿で提案した改良手法に基づく電 子透かしの埋め込み及び抽出機能をWindows パソコンに実 装し, CD 音楽素材に対して, $\langle 3 \cdot 6\rangle$ 節で述べた最適化手法 を適用して最大容量のデータを埋め込み, 抽出実験を行っ た結果を以下記す。埋め込み方式として, 図 1 に基づくス テレオ・空間分割方式, 図 3 , 図 4 に基づくモノラル周波数 2 分割および 3 分割方式, そして図 6 に基づく時分割方式 としては, 文献( 7 )記載のハニング空関数分割方式と, 本稿 で提案した非対称な窓関数を使用した方法の 2 通りを試し, 全 5 通りで実験を行なった。〈3・1 節で述べた $\mathrm{R}$ チャンネ ルから L チャンネル側に成分を移動させ, L チャンネル側 の成分を強調する付加処理については, 図 1 に基づくステ レオ・空間分割方式を除く 3 方式に全て適用した。

使用したスピーカ及びマイクロフォンはソニー製で各々 $50 \mathrm{~Hz}$ 以上の帯域をもつもので, マイクロフォンは左右 $120^{\circ}$ の指向性があるステレオタイプのものを使用し, モノ ラル方式の場合は指向性をオフにして L 側スピーカに近づ けて使用した。音響信号の再生レベルはマイクロフォンで 受けて曲全体で飽和しないレベルに固定して行い, 同じ再 生信号レベルで携帯電話（Vodafone V603SH）をスピーカ に近づけ，携帯電話の音声録音機能を使用して 1 曲分を録 音し, 録音された圧縮音声ファイルを $\mathrm{PC}$ に転送して抽出処 理を行った。

[実験条件 1$]$

・音楽素材 : DNP イメージソング「響き合う心」

4 分 21 秒全曲 $(44.1 \mathrm{kHz}, 16 \mathrm{bits}, 2-\mathrm{ch})$

・信号処理方式 : 4096 ポイント FFT

1-20 領域（約 $200 \mathrm{~Hz}$ 以下）にデータ埋め込み

以下 80 バイトを繰り返し, 曲全体に埋め込む。各バイト には ASCII7 ビットに 1 ビットのパリティを加え, 抽出時 にパリティエラーになったデータは読み捨てる。

DNPgroup_ImageSong,Sharing-a-Dream,MusicByTak aoKisugi,SongByEPO,(C)DNP2002-2005

表 1 に示される通り，マイクロフォンによる非接触精度 においては, 図 1 のステレオ法がベストであるが, モノラ ル法においては今回提案のモノ 2 (図 6)・WF2 手法が最良 となった。そこで, 以下の通り, WF2 の手法を用いて埋め 込夕領域を拡大し, 携帯電話で抽出する追加実験を行なっ た結果，1-40 領域（( 3 )( 8 )式において $\mathrm{M}=40)$ まで拡大寸 れば安定して抽出できた。抽出データのバイト数はパリテ イチェックを通り, 1 バイト中に 1 ビットの誤りも発生しな かったデータをカウントした。

[実験条件 2] 図 $6 \cdot \mathrm{WF} 2$ 埋め込み手法

1） 1-20 領域（約 $200 \mathrm{~Hz}$ 以下）に埋込み：212

2) 1-30 領域（約 $300 \mathrm{~Hz}$ 以下）に埋込み：248

3） 1-40 領域（約 $400 \mathrm{~Hz}$ 以下）に埋込み：263

[携帯電話による非接触抽出結果]

1）1-20 埋め込み 抽出データ：153 bytes 


\section{表 15 通りの埋め込み方式による抽出実験}

Table 1. Extraction Experiments by Five Kinds of Embedding Methods.

\begin{tabular}{|l|c|c|c|c|c|}
\hline \multirow{2}{*}{ Embedded Method } & Stereo & \multicolumn{2}{|c|}{ Mono 1 } & \multicolumn{2}{l|}{ Mono2 (Fig.6) } \\
\cline { 2 - 6 } & Fig.1 & Fig.3 & Fig.4 & WF1 & WF2 \\
\hline $\begin{array}{l}\text { Number of characters Embedded to } \\
\text { the source signal }\end{array}$ & 243 & 187 & 226 & 213 & 212 \\
\hline $\begin{array}{l}\text { Extracted characters from embedded } \\
\text { digital uncompressed data }\end{array}$ & 243 & 187 & 226 & 213 & 212 \\
\hline $\begin{array}{l}\text { Extracted characters from MP3 (56kbps) } \\
\text { compressed digital data }\end{array}$ & 239 & 182 & 219 & 206 & 204 \\
\hline $\begin{array}{l}\text { Extracted characters from resampled } \\
\text { data through analogue audio lines }\end{array}$ & 242 & 168 & 213 & 189 & 192 \\
\hline $\begin{array}{l}\text { Extracted characters from resampled } \\
\text { data through speaker and microphone }\end{array}$ & 207 & 96 & 161 & 154 & 178 \\
\hline $\begin{array}{l}\text { Extracted characters from resampled } \\
\text { data through speaker and cellphone }\end{array}$ & & 13 & 149 & 122 & 154 \\
\hline
\end{tabular}

DNoup_Imageong,Saringa-reamMuscByTkaoKisug,on gPO,(ODP2002-2005NPgrouImageSng,Sharing-a-remMsi c>isuoByEP,(C)DP2002-2DPgo_IgSong,Sharng-a-Dream MuTaaoKisugi

2) 1-30 埋め込み 携帯電話抽出データ : 205 bytes

Pgrup_ImageSong,Sharing-a-Dream,uicByTkaoKisugi, SongByEP(C)DNP0-20NPgrop_IageSong,Sharng-a-Dre, MusiByTaaoKisugi,SngByE,(C)D0-20DNPgru_ImageSon g,Sharg-a-Deam,MicyTakoKisugi,S=ngByEPO,(C)2002-2 005DNPgroup_Im

3) 1-40 埋め込み 携帯電話抽出データ：234 bytes

NPgroup_ImageSong,Shaing-a-ream,MusicByTkaoKis ui,SongByEPO,(C)DNP202-2005Pgroup_ImagSong,harin g-a-Drem,MusicBTkaoKisui,SngByEPO,(C)DNP2002200 5DNPrp_mageSoghring-a-Dream,MusicByTkoKisugi,So ngyEPO,(C)DNP2002-2005DNroup_ImageSong,Sharing

\section{5. あとがき}

本提案の電子透かし埋め込み方式は, 先提案のステレオ 方式に比べると劣るが，モノラル方式においては顕著な抽 出精度の改善が見られ，マイクロフォンによる非接触抽出 では，80\%近い埋め込み情報を抽出できることを確認でき た。抽出できなかった $20 \%$ のバイトデータにはパリティエ ラーを含む平均 2 ビットの誤りがあり, ビット抽出精度は 95\%であった。ただし，先いずれの提案手法に比べても， 原理的に位置ずれの影響を受けやすく，携帯電話による抽 出精度は先提案図 4 の手法の方が良好な場合がある。携帯 電話による検出においては，マイクロフォン単体検出時に 比べ，マイクアンプと音声圧縮の影響が加わるが，主にマ イクアンプに内蔵する低域カットフィルタの影響が大きい と思われる。今後種々の機種の携帯電話を用いて実験を重 ねる予定である。

また，埋め込み可能なビットレートとデータ抽出精度を 更に向上させ，エラー訂正符号を付加し，リアルタイムに 信頼性の高い抽出ができる実用ツールを開発するととも
に, 抽出ソフトウェアを携帯電話等に実装し, 民生用の安 価なスピーカで再生中の楽曲情報や関連する情報サイトの URL 等を抽出できるようにする予定である。

更に, 本稿で提案した, 電子透かし埋め込み手法を, 新 規な音響無線タグ技術として, 端末内のコンテンツやロボ ットなどを音楽と同期させて遠隔制御したり, 完成楽曲か らミックスダウン前の音楽素材や合成条件等を追跡可能に する音楽制作業務のトレーサビリティに㐫用することを検 討する予定である。

(平成 17 年 9 月 20 日受付, 平成 18 年 3 月 14 日再受付)

\section{文献}

（1）中山 彰・陸金林・中村 哲・鹿野清宏 :「心理音響モデルに基づい たオーディオ信号の電子透かし」, 信学論, Vol.J83-D2, No.11, pp.2255-2263 (2000-11) (in Japanese)

(2) C. -T. Wang, T. -S. Chen, and Z. -M. XU : "A Robust Watermarking System Based on the Properties of Low Frequency in Perceptual Audio Coding", IEICE Trans., Vol.E85-A, No.6, pp.1257-1264 (2002-6)

(3) D. Kirovski and H. S. Malvar : "Spread-spectrum watermarking of audio signals", Signal Proc., IEEE Trans. on Acoustics, Speech, and Signal Proc., Vol.51, No.4, pp.1020-1033 (2003-4)

（4）中村高雄・片山 淳・山室雅司・曽根原登 :「カメラ付携帯電話機を 用いたアナログ画像からの高速電子透かし検出方式」, 信学誌, Vol.J87-D2, No.12, pp.2145-2155 (2004-12) (in Japanese)

(5) T. Modegi : "Development of Audio Watermarking Technique Robust to Analogue Conversion", Proceedings of the 67-th IPSJ National Convention, Vol.3, pp.271-272 (2005-3) (in Japanese) 茂出木敏雄: 「オーディオのアナログ而性電子透かし埋め込み技術の 開発」, 情処学第 67 回全大, Vol.3, pp.271-272 (2005-3)

(6) T. Modegi : "Development of Contactless Sensible Watermark Embedding Technology for Audio Signals", Tech. Report of IEICE, Vol.EA2005-4, pp.19-24 (2005-4) (in Japanese) 茂出木敏雄: 「非接触抽出可能な音楽への電子透かし埋め込み技術の 開発」，信学技報（応用音響研究会）, EA2005-4, pp.19-24 (2005-4)

( 7 ) T. Modegi : "Development of Audio Watermark Technology to be Extracted Contactlessly by Cell Phone", Tech. Report of IEICE, Vol.MoMuC2005-24, pp.49-54 (2005-7) (in Japanese) 茂出木敏雄: 「携帯電話で非接触抽出可能な音楽への電子透かし埋め 込み技術の開発」, 信学技報 (モバイルマルチメディア通信研究会), MoMuC2005-24, pp.49-54 (2005-7)

(8) T. Modegi : "Automatic Synthesis of Background Music Track Data by Analysis of Video Contents", IEEJ Trans. on Electron., Inf. and Syst., Vol.125-C, No.7, pp.1004-1010 (2005-7) (in Japanese)

茂出木敏雄: 「映像コンテンツ解析による BGM サウンドトラックの 自動生成」, 電気学会・電子情報システム部門誌, Vol.125-C, No.7, pp.1004-1010 (2005-7)

(9) T. Modegi : "Development of Contactless Content-ID Sensing System for Watermark Embedded Audio Signals", Proc. of SICE Annual Int. Conference 2005 in Okayama, pp.1394-1399 (2005-8)

茂出木 敏 雄 （正員） 1959 年 11 月 16 日生。 1982 年 3 月

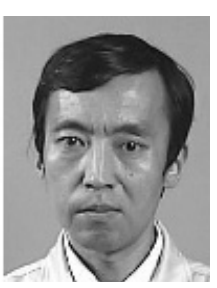
千葉大学工学部電子工学科卒業。同年大日本印 刷株式会社入社。1995 年 10 月〜 1998 年 3 月 郵政省・通信総合研究所の特別研究員としてマ ルチメディア関連の研究に従事。現在, 同社情 報コミュニケーション研究開発センターに勤 務。2003 年 4 月より, 尚美学園大学芸術情報 学部非常勤講師兼任。 